This is an Accepted Manuscript of a book chapter published by Routledge in Routledge Handbook of Turkish Politics (2019), available online: https://doi.org/10.4324/9781315143842-18

This version downloaded from SOAS Research Online: https://eprints.soas.ac.uk/32788/

\title{
The Kurdish Question
}

\section{Zeynep N. Kaya and Matthew Whiting}

Following the collapse of a half-hearted peace initiative in 2015, Kurdish violence against the Turkish state escalated once again, with high profile attacks in Ankara and İstanbul as well as in the southeast of the country. The attacks were spearheaded by the Kurdistan Freedom Hawks (TAK) and the Kurdistan Workers' Party (PKK). Both groups are violent manifestations of Kurdish nationalism and serve as reminders of the Turkish state's failure to deal with the Kurdish question. Although the TAK has always been seen as more ruthless than the PKK, from which it split in the early 2000 s, the muted condemnation of a particularly violent TAK attack in 2016 from Cemil Bayık, co-founder and co-leader of the PKK, highlighted the shared interpretation and acceptance of the need for violence by both groups. After the attacks, Baylk stated "Kurdish cities are burned - destroyed. Civilians are dead. Their culture is being trampled upon. Thousands are forced to flee their homes. If the TAK take action in these conditions the people will be sympathetic" (BBC News 2018). The Turkish state's response to the attacks was to block media reporting on the issue, to reinforce its military pursuit of Kurdish radicals in southeast Turkey and Syria, and to engage further in the suppression and persecution of all Kurdish politics, whether this was peacefully expressed or not. The number of political figures, journalists and activists (often spuriously) imprisoned for supporting Kurdish terrorism jumped significantly following 2015, while the ruling Justice and Development Party (AKP) saw electoral gains for its tough response to terrorism (Çiçek 2018).

One of the particularly interesting aspects of this escalation in violence, and the state's response to it, was the backdrop against which they occurred. The violence was the fallout of the collapse of two peace initiatives with the PKK over the previous decade. While recent attacks were condemned by Western governments, the fighters of the YPG (People's Protection Units), a Syrian Kurdish military organisation closely linked to the PKK, were being praised, supported and equipped by British and US forces for their role in the fight against ISIS. ${ }^{1}$ Western countries accept the PKK's designation as a terrorist group, but when the YPG (and there is a large degree of cross and dual membership between the YPG and the PKK, see Kaya and Lowe 2018) fight in Syria against ISIS, they are lauded. This position becomes even more incoherent when it is noted that for Kurds, there is no difference in their motivation whether they are fighting in Turkey or Syria. In both instances, they see their role as protecting Kurdish communities from suppression and attempting to advance their desired political system of democratic confederalism within the host country. It is little wonder then that the Turkish state is left frustrated by the West's response to what it sees as terrorists undermining its authority from both within its borders and from neighbouring Syria. This, in turn, incentivised the AKP and its leader, Recep Tayyip Erdoğan, to seek alliances with Russia in an effort to shape the future of Syria, rather than relying on its relationship with the US and Europe.

From this snapshot it is evident that the Kurdish question in Turkey is highly intractable, having proved stubbornly resilient in the face of half-hearted peace initiatives and full-blooded violent confrontation with Turkey's Armed Forces. It has domestic, regional and international dimensions which further complicate the picture. Kurdish nationalists seek to carve out a space in Turkish politics that recognises what they claim are its distinctive culture, language, and political preferences - a distinctiveness the Turkish state has historically denied until recently. In its radical manifestation, Kurdish ethno-nationalism has used rebellions and violent conflict as part of this political struggle ever since the foundation of the Turkish republic and also during Ottoman times. As such, the Kurdish question has deep historical roots and the very 
foundation of the Turkish state and its political institutionalisation laid the ground for a conflict between a dominant Turkishness and a peripheral Kurdishness. At its heart, the Kurdish question is a political issue - for Kurds it is about demanding respect for their human and cultural rights, a quest for self-determination (initially in the form of secession but now seeking increased power for local administrations) and political recognition. However, for the state it is simply a violent challenge to its authority and its territorial integrity and a challenge to the majority will of Turks. Therefore, traditional Turkish state responses to the Kurdish challenge have been non-recognition and violent and non-violent suppression.

Identifying the number of Kurds within Turkey is a difficult task given that since the 1930s and until very recently, Turkey has denied that the Kurds existed as a distinct minority and therefore did not count them separately. Population estimates vary widely with McDowall's (1989) admittedly now somewhat dated estimate of 8.5 million, while the CIA Factbook (2017) estimates Kurds to be $19 \%$ of the population (approximately 15 million), compared to Kurdish groups estimates of closer to 20 million. ${ }^{2}$ Originally located in the east and southeast of the country, these have historically been the most deprived and underdeveloped regions of Turkey, with the relative economic and social position of the Kurds being further disadvantaged by the historically nomadic and then farming lifestyle of the Kurds (White 2000, 93). Industrialisation and economic liberalisation generated fewer gains for Kurdish populated regions of Turkey compared to the rest of the country, adding further grievances to Kurdish nationalism. Although the state has embarked on some limited initiatives to tackle this, economic underdevelopment and Kurdish violence have formed somewhat of a negative reinforcing cycle that further complicates the picture.

In this chapter we trace the origins of the 'Kurdish question' in Turkey - a rather euphemistic phrase for a deeply troubling and violent cleavage that strips the issue of its intensity (much akin to the use of the phrase 'The Troubles' to describe the conflict in Northern Ireland for 30 years). We examine how it emerged, how to characterise the nature of the confrontation and the basis of different perspectives on the issue, how it evolved since Ottoman times through to the foundation of the Republic until the present day, and the future prospects for the Kurdish question in Turkey. Throughout we wish to make two modest but important points: (1) the Kurdish question needs to be placed in its historical context for any adequate understanding; and, (2) at its core is a political contestation whose form and shape is defined by the political response of the state as well as its own internal political dynamics.

\section{Change and Continuity in the Kurdish Question in Turkey}

We can broadly define the Kurdish Question as referring to the political demands of the Kurdish community, originally located in the east and southeast of the country, for greater recognition. These demands have changed over time from seeking territorial and tribal power, to demanding a separate state, to decentralisation within the established Turkish state. In other words, it has always had a territorial dimension, but whether that territory is independent or accommodated within the Turkish state has shifted. The other important dimension is how the state should respond to the very questioning by Kurdish nationalists of its legitimacy. This has been largely consistent for most of the duration of the Turkish republic - namely denial of the distinctiveness of Kurds and instead emphasising shared identities (labelling Kurds 'mountain Turks' or focusing on the shared Sunni Muslim roots of Turks and Kurds), suppressing political challengers and increasingly securitising the issue in the name of protecting Turkey. More recently, this changed somewhat under the AKP when they explored basic cultural recognition 
and a possible peace initiative, but this did not last and today it appears to be a return to business as usual. As such, we can see change but primarily continuity on both sides.

\section{Kurdish revolts in the Ottoman Empire}

Kurdish nationalist historiography typically lauds revolts led by Kurdish tribal leaders in the late Ottoman period. This is not only because their violent resistance against a more powerful state is admired, but it is primarily done in an effort to 'prove' the existence of a distinct Kurdish nationalist consciousness and Kurdish ethnic self-identification going back centuries (Hassanpour 2003, 148). In reality, the nature of these revolts is deeply contested as to whether they were nationalistic or whether they were simply reactions to the multi-ethnic Ottoman Empire's centralisation policies (Olson 1991).

The $19^{\text {th }}$ century Ottoman Empire witnessed several Kurdish tribal revolts. Most notable among these were revolts led by Kör Muhammad Pasha, Bedirhan Pasha, and Sheikh Ubeydullah. ${ }^{3}$ The centralisation policies of the Ottoman Empire provided the main political context for these revolts. The Ottoman Empire's foreign influence and internal control was in decline throughout the $18^{\text {th }}$ and $19^{\text {th }}$ centuries and, therefore, under Sultan Mahmud II and later Abdulmecid, ${ }^{4}$ the Ottomans began to implement several reforms, including centralisation policies that sought to revive the power and strength of the Empire. Centralisation in these reforms sought to eliminate the authority of increasingly powerful ayans (local lords). Many scholars and present-day Kurdish nationalists consider these as the first Kurdish nationalist rebellions that occurred in reaction to the destruction of emirates and principalities by the Ottomans (Jwaideh 2006).

Yet other scholars argue that although these tribal leaders claimed that their aim was to 'liberate Kurdistan', essentially their revolts were aimed at regaining the status they lost as a result of the process of centralisation (Tahiri 2007). These revolts must be understood in the context of complex centre-periphery relations between local rulers and the Ottoman state. This relationship was based on the assumption that the rebels perceived resistance as a means of bargaining and negotiation between the centre and periphery (Mardin 2008). Therefore, Kurdish revolts in the $19^{\text {th }}$ century can also be understood as attempts to force the state into a new deal in order to regain their loss of status and authority (Bozarslan 2003). Another important factor that led to reactions by Kurdish tribal leaders was the increasing recognition of non-Muslim communities as part of the reforms Ottomans initiated in early nineteenth century. For instance, Sheikh Ubeydullah was concerned about possible Armenian control in Kurdistan, especially because of Article 71 of the 1878 Treaty of Berlin, which promised Armenians certain 'improvements and reforms' and guaranteed their 'security against Circassians and Kurds' (Jwaideh 2006, 83). All these developments, together with increased Christian missionary activity, led Kurdish tribal leaders to feel threatened and incentivised revolution against the state. Whether these revolts were undertaken in the name of Kurdish nationalism, however, is more debatable. Rather it seems that when there was an advantage in doing so, Kurdish tribal leaders were happy to make deals with the Ottoman state.

Nonetheless, this early period of Kurdish revolts set a precedent for the subsequent development and crystallization of Kurdish nationalism. When it became clear that the dissolution of the Ottoman Empire was inevitable and that Ottomanism was no longer feasible, Kurdish nationalism began to emerge as a distinct movement separate from pan-Turkism and pan-Islamism (Klein 2007). Of course, we need to be cautious is asserting that this era represented the emergence of a homogenous Kurdish nationalism and that all Kurds now 
aspired for their own state. Rather the picture was much more mixed, with some Kurdish leaders seeking autonomy within the Empire while others sought an independent state. Indeed, two of the founding members of the Committee of Union and Progress ${ }^{5}$ were Kurdish who saw the place of the Kurds as being within a reformed Empire or a future Turkey. However, what is clear is that these early revolts gave an impetus to separatist Kurdish nationalism, which was then emerging in line with the political opportunities of the time and the rise of the principle of self-determination in the post WWI era. When the Treaty of Lausanne was ratified in 1923, which led to the foundation of the Republic of Turkey, it was clear that self-determination would not extend to the Kurds. Instead Kurds were to sit inside a new Turkish state, setting the scene for future conflict.

\section{Kurdish politics in the early years of the Republic}

Along with secularism, Turkishness was adopted as the identity of the new Republic. İsmet İnönü, second prime minister of Turkey, declared in 1925: "as Turks are in the majority, other groups do not have any power. Our mission is to Turkify non-Turkish groups in the Turkish vatan [homeland]. We are going to extirpate groups who oppose Turks and Turkishness" (quoted in Özkan 2012). In other words, the only way Kurds could gain full political recognition and participation was by being Turks and giving up on any pretence of being Kurds. The new Republic was also intent on modernising its creaking foundations and therefore the underdeveloped, poorly educated and 'backwards' southeast was a problem for Ankara who sought to bring it tighter under its control. Ankara expropriated landholdings in the region and distributed them to Turks, not local Kurds, and further compounded this by placing restrictions on the use of the Kurdish language (Barkey 2017). These factors alienated the politically minded and religious Kurdish elite from the new state, setting a hostile relationship and one that was to be characterised by further violent revolt. In fact, Kurdish groups revolted against the state 28 times between 1923 to 1938 (Başaran 2018, 17). The response of the state set the tone that would be followed over the coming decades.

The first large scale Kurdish rebellion of the new Republican era was the 1925 Sheikh Said Revolt. The organisation behind the revolt was Azadi (meaning 'freedom'), a secret organisation of Kurdish officers and tribal leaders founded in Erzurum in 1923. Sheikh Said, a well-known Sunni sheikh, was selected to be the leader of the revolt in the hope that a revolt with a religious character would make mobilisation easier at a time when Kurdish nationalism was weak among the masses (Tahiri 2007). The weakness of the idea of Kurdish nationalism is evident from the fact that the revolt drew support mainly from Zaza-speaking Sunni Kurds while Alevi Kurds from Dersim as well as some Sunni Kurds and tribes in Van, Diyarbakir and Elazığ refused to support him and joined in the suppression of the revolt. The revolt was easily defeated and Sheikh Said and other Kurdish leaders were executed for the crime of attempting to establish an independent Kurdish state. For Barkey and Fuller (1998), the state's response represented a shift from ignoring the Kurdish issue to adopting a policy of violence towards the Kurds.

The execution of Said and the ease and severity with which the revolution was put down, did not prevent further attempts at revolution over the next decade. This period of tribal and local revolt was to end with the violent suppression of the Dersim revolt in 1938. At the time, Turkish government policies, particularly land confiscations and deportations, were sources of discontent among Kurdish tribal leaders and sheikhs. A religious leader, Sayyid Reza, led the Dersim revolt from 1937-8 but it too was ultimately easily defeated by the more powerful 
Turkish forces and it exposed divisions within Kurds as much as between Kurds and Turks. The state's response was exceptionally heavy handed with thousands of Kurds killed and many more displaced while Dersim was renamed Tunceli (a more acceptable Turkish name) in the process.

The response to Kurdish revolts in this first decade confirmed the new state's direction of the assimilation of the Kurds into the Turkish state, including by force where necessary. Additionally, the state embarked on a programme of the repression of Kurdish nationalist culture and language. Kurds were forcibly exiled to different parts of the country and the official state media stopped referring to them as 'Kurds'. Yet alongside this, if Kurds accepted a Turkish identity and participated in the system as Turkish citizens, a full range of political, economic and social opportunities were available to them.

\section{Kurds in the Early Multiparty Era - The Calm Before the Storm}

Kurds were mostly politically inactive in the 1940s and 1950s. After the Dersim revolt, there was a lack of localized rebellion or Kurdish leadership to lead any future revolts. The Turkish state largely maintained its position of suppressing a distinct Kurdish identity, but the arrival of multiparty politics and the Democrat Party (DP) diffused tensions somewhat. The DP, which was electorally very successful in the east and southeast, agreed to ease some cultural restrictions and to reduce oppressive local policing (Barkey and Fuller 1998, 14). As such, the 1960s was a period of relative peace and the Kurdish question fell into the background, eclipsed by other more pressing political developments.

By the 1970s, politically active Kurds were joining leftist movements during a period of wider left-wing mobilization throughout the country as a whole. From the left's perspective, Kurdish groups were natural allies given the high levels of relative socio-economic underdevelopment in southeast Turkey, while Kurds hoped that the left's confrontation with the state could also be used to advance their position within the country. However, over time Kurdish nationalists who threw their lot in with the left became frustrated with the lack of progress on Kurdish issues and seeming levels of apathy amongst mainstream leftists, eventually leading to the distinct emergence of Kurdish movements with leftist inclinations. It was out of one such leftist movement that the PKK emerged in 1974 and adopted the aim of liberating Kurdistan and establishing an independent, united and socialist Kurdish state. At this time there were also the first electoral breakthroughs for Kurdish nationalists running as independents but clearly affiliated with the PKK position. In the 1977 local elections, Medhi Zana was elected mayor in Batman, while Orhan Alpaslan in Ağrı and Edip Solmaz in Diyarbakır repeated the feat the following year (Natali 2005, 106).

\section{Coup Politics and the Violent Radicalization of the Kurdish Question}

From the 1980s onwards the Kurdish question was to become synonymous with a conflict between the Turkish military and the PKK. This enabled the Turkish military, as guardians of the secular and modern Republic, to take further control of the state's Kurdish policy, something it had largely been doing anyway since the 1971 coup at least. The 1980 coup proved to be a seminal event for defining the trajectory of the Kurdish question, following which there was increasing violence from both sides and the securitisation of the Kurdish question was further entrenched. 
Although the coup was ostensibly aimed at protecting the state from leftist radicals, the Kurdish movement was also targeted. During the period of the military rule (12 September 1980 to 6 November 1983), many Kurdish activists were imprisoned and tortured. Additional oppressive measures were imposed, including further restrictions on Kurdish language and culture. This had the effect of bonding the Kurdish movement around a shared notion of resistance, further reinforced by the use of myth (Güneş 2017). When this was combined with the PKK's ability to use local politics and local conditions on the ground to its advantage (Romano 2006), a radical Kurdish movement was able to emerge on a stronger and more coherent level than had been previously seen in Turkey.

The PKK's goal was to overthrow Turkish rule (economically as well as politically, given its Marxist inclinations) and to unify Kurds and secure a separate state. Their guerrilla campaign began in 1984 and, in the mountainous terrain of southeast Turkey combined with porous borders with Iraq and support from Syria, was to prove remarkably resilient. Drawing on local resources as well as support from the Kurdish diaspora and Kurds in neighbouring countries, the number of PKK recruits and levels of violence increased steadily throughout the 1980s and reached a high in the 1990s (Tezcür 2014; Romano's chapter in this volume). Nonetheless, the Turkish state was clearly never going to be defeated or forced into a position to concede to the demands of the PKK and instead it responded with a scorched earth policy. Villages were razed, whole towns became securitised, people were forcibly relocated, and arrests, detention and torture continued. This had the consequence of increasing the popularity of the PKK within Kurdish communities.

Although this was the predominant picture for the 1980s and 1990s, the Kurdish issue was not completely static. For example, Turgut Özal, prime minster for much of the 1980s and president from 1989-1993 for the Motherland Party, attempted to move beyond a purely security-based response to the Kurds. He criticised an exclusively military approach and advocated pursuing cultural, economic, social and political measures too, representing the first time a Turkish government saw the issue as a political one and not just a security issue (Efegil 2011). In part as a result of Özal's initiative, the PKK declared a unilateral ceasefire in 1993 (albeit it did not last for more than a few months). Abdullah Öcalan, leader and co-founder of the PKK, was subsequently captured and arrested in Kenya with US help after being forced to leave his safe-haven in Syria following Turkish pressure on the Assad regime, and he remains imprisoned on İmralı island to this day. Soon after Öcalan's imprisonment, the PKK declared the movement was no longer striving for full independence but now sought recognition and autonomy within the Turkish state and called on the government to engage in negotiations. The call went unheeded and the military clearly won out over Özal's suggested change in direction.

Attempts to advance Kurdish goals through the electoral arena also became more prominent in the 1990s. The first openly Kurdish political parties emerged to compete in elections. The People's Democracy Party (HADEP) performed relatively well in the southeast in the 1995 general election, but only secured just over 4 per cent of the national vote share, falling short of the required 10 per cent threshold needed to gain seats in the Grand National Assembly. Successive Kurdish parties and loose electoral alliances polled at somewhere between four to six per cent in general elections in 1999 and 2002. Although these parties failed to gain any representation, they did raise the profile of Kurdish politics. However, the state made it clear that the political route was no more of a viable route for Kurdish aspirations than a military one. Kurdish parties were typically met with party bans and harassment to which Kurdish groups responded by reinventing themselves or running as independents (Öktem 2011). In this 
way, a kind of cat and mouse game played out. From the state's perspective, Kurdish political parties were best seen as extensions of the PKK that aimed to bolster its campaign and goals and therefore an equal threat to the state. However, the suppressive response served to further restrict the scope for the Kurdish political movement, further entrenching their claims that a military campaign was necessary and justified.

\section{The AKP and the Kurdish Question - From Fresh Thinking to More of the Same}

The AKP in office appeared initially to offer something different to their governing predecessors that gave them an advantage in their relationship with the Kurdish population. As a mildly Islamist party that emerged out of the Welfare Party, its leadership and members also had a history of being politically suppressed and harassed by the state. What is more, the pious and socially conservative dimension to the party had a natural resonance with the Kurdish southeast. ${ }^{6}$ The AKP positioned itself as a party that would represent those who were left behind in Turkey's recent economic modernization, and this resonated as much with the economically under-developed southeast as it did with the conservative electorate of Konya. Alongside this sat the EU accession process, which saw the treatment of the Kurds as a human rights issue that needed to be tackled if Turkey was to advance its membership aspirations. Therefore, there were significant incentives for the AKP to explore ways to ameliorate the position of Turkey's Kurds and initially there was a break with the traditional approach to managing the issue.

During its first term in government, the AKP granted limited rights to broadcast in Kurdish and for Kurdish pupils to receive their education in their mother tongue. Alongside this, other EUincentivised measures also meant that the new government's policy significantly differed from what came before. In a speech in 2005, Erdoğan even went so far as to state that the 'state has made mistakes about the Kurdish issue' (Özkan 2011) and to claim that Kurdishness should be recognised as a sub-identity of Turkishness. The abolition of the death penalty, the release of former Kurdish MPs from prison, and the end of emergency rule in the southeast alleviated local tensions. Needless to say, the opposition Republican People's Party (CHP, essentially the modern day inheritors of Atatürk's legacy), the Turkish-nationalist Nationalist Movement Party (MHP), and many senior military figures, opposed any change in the traditional policy towards managing the Kurdish question. Nonetheless, the new direction led to an electoral boost for the AKP in southeast Turkey in the 2007 election, and optimists asserted this might imply that moderate Kurds were peeling away from the PKK and its affiliated parties in return for cultural concessions from the state.

Changes in policy from the AKP were also mirrored by important developments from those at the forefront of the Kurdish movement. As already noted, the capture of Öcalan in 1999 had resulted in a ceasefire from the PKK, which reduced immediate tensions on the ground. Many Kurds put their hopes behind the EU accession process as a way of advancing their position in Turkey. At this time, the first of two peace initiatives began in 2005, culminating in covert talks between Turkish intelligence, government representatives and members of the PKK in 2008. While these collapsed in 2011 due to a lack of will on both sides, additional talks were undertaken, directly and more openly, between representatives of the AKP government and Abdullah Öcalan and members of the Kurdish political parties. These were held between 2013 and 2015, after which they collapsed amidst tensions over the Syrian war and a lack of general progress (for full details, see the chapter by Çandar in this volume). 
In the course of these talks the parameters of the Kurdish question as it plays out today can be seen. Whilst largely still driven by a desire for greater political recognition, it now also requires a war to peace transition. Öcalan has repeatedly indicated that the PKK is ready to negotiate a solution with the Turkish government that involves decentralisation for the Kurds within the existing boundaries of Turkey, a system he labels 'democratic confederalism' (Öcalan 2011). Singing from largely the same hymn sheet, Selahattin Demirtaş, the leader of the People's Democratic Party (HDP), has also called for a reorganisation of the administrative structure of Turkey based on the principle of decentralisation. ${ }^{7}$ Yet it became clear that limited cultural recognition was as far as the AKP was willing to go and both sides were anxious about retaining the support base they had built in the southeast, which limited their desire to make further any concessions.

External factors, which were previously so propitious, today incentivise the AKP to return to a security based response. An EU accession process no longer looks viable for Turkey in the immediate future; the Syrian war and increased independence of the Kurdistan Region of Iraq have set worrying/encouraging (depending on your perspective) precedents for Kurdish autonomy; increasing centralisation of power in the hands of an authoritarian Erdoğan prohibits any decentralisation or power division; and, electoral dynamics bring the AKP and Turkishnationalist MHP together as well as incentivising the AKP to restrict the increasing electoral popularity of the HDP. These factors have all pushed the government towards a traditional militant policy to manage the Kurdish question. Therefore, since the collapse of the second peace initiative, and especially following the coup attempt in July 2016 and the ensuing period of emergency rule, the AKP has relentlessly embarked upon criminalising Kurdish activism and securitising the issue once again. At the same time, radical Kurdish nationalism has escalated its violence amidst the wider regional dynamics.

The AKP's change of tactic from talks and pursuing a Kurdish opening to instead securitising the issue is also the outcome of HDP's electoral success since the presidential elections in 2014. The HDP's co-leader, Demirtaş received 9.8 per cent of the vote share, indicating the possibility that the party could pass the 10 per cent threshold needed to gain representation in the legislature. This was something the party duly achieve in the 2015 June general elections. The party's strategy to become a political party of Turkey and focus on improving the situation of all marginalised communities including the Kurds, while maintaining its leftist welfare distribution policies appealed to the liberal minded Turkish electorate as well as Kurds who do not support the PKK. HDP's breakthrough in the 2015 elections meant that Kurdish MPs entered the Parliament as a party for the first time, and prevented the AKP from securing a majority. Erdoğan's response was to hold a snap election just five months later, going back to the traditional securitised response to the Kurdish question, criminalising Kurdish MPs, stripping 50 of the their 59 MPs of their parliamentary immunity, and imprisoning many of them. Demirtaş has been detained in prison since November 2016 and ran his election campaign for presidential elections in June 2018 from prison. In the mean time, clashes between the Turkish army and the PKK increased during which the PKK used urban warfare tactics, which led to a highly severe response by Turkish security forces and the displacement of large numbers of people from cities and towns in the southeast. Additionally, the Turkish army started its cross-border military campaign in Afrin in Syria, which was under de facto Kurdish control, and took the city. All this served to boost the electoral fortunes of the AKP and entrench the traditional dynamic on both sides. The Kurdish question, the PKK's tactics, and the state's response were all back to business as usual it would seem. 


\section{Conclusion}

The failure to resolve the Kurdish question has had deep costs, for Turks, Kurds and for the state in both blood and treasure. Given the pessimistic history of the Kurdish question, is there any reason to be optimistic for a change in the future? The answer in the immediate future is certainly not. Radical groups tend to moderate when internal political reappraisals are met with political opportunities for inclusion from the state (Whiting 2018). However, in the case of Kurdish radicalism, there is little hope for an internal reappraisal when Kurdish leaders fear a decline in violence may threaten their survival and influence (Tezcür 2010). What is more, there is no sign of the state reopening any opportunities for dialogue any time soon (see Çandar in this volume). Regional dynamics in the form of the Syrian war also restricts future prospects for a resolution in two ways. Firstly, fears that an autonomous Kurdish region (Rojava or Western Kurdistan) will emerge on its border restricts the opportunities the Turkish state is willing to extend to its Kurdish population and it willingness to engage the PKK in dialogue. Secondly, the Syrian war increased divisions between different Kurdish groups in the region and the resulting intra-group dynamic restricts the concessions Turkey's Kurds are willing to consider (Kaya and Whiting 2016).

The medium to long-term looks no better. Given the historical nature of the Kurdish issue, fundamental structural changes in the state's approach are necessary, but at no stage in the history of the Republic has there been any sign of such a change becoming embedded policy. Furthermore, the political nature of the Kurdish question, with both sides squeezing the room for manoeuvre of the other while also using the actions of each other to justify escalations, gives further cause for pessimism. All conflicts can appear intractable until they are resolved and cases like the FARC and the IRA show that deeply militaristic movements can change direction. But again this brings us back to the need for a reappraisal on both sides in order to achieve a breakthrough. With no sign of defeat or victory forthcoming for either side, a negotiated settlement looks highly necessary but also highly unlikely.

\footnotetext{
${ }^{1}$ Britain denies ever having equipped the YPG or given it any weapons but it does provide air and other forms of support. A recent UK Parliament Foreign Affairs Committee report shows that the FCO holds an incoherent position given it claims to reject the PKK but has not fully examined the links between the YPG and PKK. See House of Commons Foreign Affairs Committee (2018).

${ }^{2}$ Over 22.5 million Kurds live in Turkey, new Turkish statistics reveal, EKurd Daily, 20 September 2012, https://ekurd.net/mismas/articles/misc2012/9/turkey4166.htm

${ }^{3}$ Interestingly, in all three of these cases the leaders of the revolts were later appeased by the Ottoman Empire with positions and appointments within the Empire, which were readily accepted.

${ }^{4}$ Sultan Mahmud reigned from 1808-1839 while Abdulmecid reigned from 1839-1861.

${ }^{5}$ The Committee for Union and Progress was an umbrella group of many diverse views that came to be associated with the Young Turk movement. It was a secret society later turned political party that called for reform of the Empire but which sought to hold the territory under its control together, albeit there was disagreement within the movement on what direction this should take.

${ }^{6}$ This was to prove a hindrance to peace a few years later when it became clear to the AKP that the southeast was a key electoral battleground they needed to win and therefore needed to restrict Kurdish parties from succeeding.

${ }^{7}$ Interview with Selahattin Demirtaş by Neşe Düzel, 'Türkiye'nin güney sınırları resmen Kürdistan olacak' [Turkey's southern borders will officially be Kurdistan,' Taraf, 10.04.2012, http://www.taraf.com.tr/neseduzel/makale-selahattin-demirtas-turkiye-nin-siniri-kurdistan.htm, last accessed 26.04.2012. BDP is the political party in Turkey that succeeded the Democratic Society Party [DTP]. DTP was closed due to its links with the PKK.
}

\section{Bibliography}


BBC News. Cemil Baylk. An Interview with Turkey's Most wanted Man. $25^{\text {th }}$ April 2016. https://www.bbc.co.uk/news/av/world-europe-36081182/cemil-bayik-an-interview-withturkey-s-most-wanted-man

Barkey, Henri. 2017. “The Transformation of Turkey's Kurdish Question.” In The Kurdish Question Revisited, edited by Gareth Stansfield and Muhammad Shareef, 211-224. London: Hurst.

Barkey, Henri, and G. E. Fuller. 1998. Turkey's Kurdish Question. Oxford: Rowman and Littlefield.

Başaran, Ezgi. 2017. Frontline Turkey. The Conflict at the Heart of the Middle East. London: IB Tauris.

BBC News. Cemil Baylk. An Interview with Turkey's Most wanted Man. $25^{\text {th }}$ April 2016. https://www.bbc.co.uk/news/av/world-europe-36081182/cemil-bayik-an-interview-withturkey-s-most-wanted-man

Bozarslan, Hamit. 2003. "Kurdish nationalism in Turkey: From tacit contract to rebellion." In Essays on the Origins of Kurdish Nationalism, edited by Abbas Vali, 163-90. California: Mazda.

CAI. 2017. The World Factbook. Turkey. https://www.cia.gov/library/publications/the-worldfactbook/geos/tu.html, last accessed August 2018.

Çiçek, Cuma. 2018. "Süreç": Kürt Çatışması ve Çözüm Arayışları ["The Process": Kurdish Conflict and the Search for a Solution]. İstanbul: İletişim.

Düzel, Neşe. 2012. "Türkiyenin güney sınırları resmen kürdistan olacak." Taraf April 10. Accessed 26 April 2012.

http://www.taraf.com.tr/nese-duzel/makale-selahattin-demirtas-turkiye-nin-sinirikurdistan.htm

Efegil, Ertan. 2011. "Analysis of the AKP Government's Policy Toward the Kurdish Issue." Turkish Studies 12 (1): 27-40.

Güneş, Cengiz. 2017. "Mobilization of Kurds in Turkey during the 1980s and 1990s." In The Kurdish Question Revisited. edited by Gareth Stansfield and Mohammed Shareef, 187-198. London: Hurst.

Hassanpour, Amir. 2003. "The making of Kurdish identity: Pre-20" literary sources." In Essays on the Origins of Kurdish Nationalism, edited by Abbas Vali, 106162. California: Mazda.

House of Commons Foreign Affairs Committee 2018 Kurdish Aspirations and the Interests of the $U K$.

https://publications.parliament.uk/pa/cm201719/cmselect/cmfaff/518/518.pdf 
Jwaideh, Wadie. 2006. Kurdish National Movement: Its Origins and Development, New York: Syracuse University Press.

Kaya, Zeynep N. and Robert Lowe. 2017. "The curious question of the PYD-PKK relationship." In The Kurdish Question Revisited, edited by Gareth Stansfield and Mohammed Shareef, 275-287. London: Hurst.

Kaya, Zeynep N. and Matthew Whiting. 2017. "Sowing Division. Kurds in the Syrian War." Middle East Policy 24 (1): 79-91.

Klein, Janet. 2007. "Kurdish nationalists and non-nationalist Kurdists: rethinking minority nationalism and the dissolution of the Ottoman Empire, 1908-9." Nations and Nationalism 13 (1): $135-153$.

Mardin, Şerif. 2008. Türk Modernleşmesi Hakkında Makaleler 4 [Articles on Turkish Modernisation 4]. Ankara: İletişim Yayınları.

Natali, Denise. 2005. The Kurds and the State: Evolving National Identity in Iraq, Turkey and Iran. New York: Syracuse University Press.

Öktem, Kerem. 2011. Angry Nation. Turkey Since 1989. London: Zed Books.

Olson, Robert. 1991. "Five stages of Kurdish nationalism, 1880-1980." Journal of Muslim Minority Affairs 12 (2): 391-409.

Öcalan, Abdullah. 2011. Democratic Confederalism. Translated by International Initiative. London: Transmedia Publishing.

Özkan, Behlül. 2011. "Kurds Could Revolt if Grievances Aren't Fixed.” Al Jazeera, $9^{\text {th }}$ July https://www.aljazeera.com/indepth/opinion/2011/06/201169131053712220.html

Özkan, Behlül. 2012. From the Abode of Islam to the Turkish Vatan. The Making of National Homeland in Turkey. New Haven: Yale University Press.

Romano, David. 2006. The Kurdish Nationalist Movement. Opportunity, Mobilization and Identity. Cambridge: Cambridge University Press.

Tahiri, Hussein. 2007. Structure of Kurdish Society and the Struggle for a Kurdish state. Costa Mesa, California: Mazda Publishers.

Tezcür, Guneş. M. 2014. "The Ebb and Flow of Armed Conflict in Turkey: An Elusive Peace." In Conflict, Democratization and the Kurds in the Middle East. Turkey, Iran, Iraq and Syria, edited by David Romano and Mehmet Gurses, 171-188. US: Palgrave Macmillan.

Tezcür, Guneş. M. 2010. "When Democratization Radicalizes: The Kurdish Nationalist Movement in Turkey." Journal of Peace Research 47 (6): 775-789.

Whiting, Matthew. 2018. "Moderation without Change: The Strategic Transformation of Sinn Féin and the IRA in Northern Ireland." Government and Opposition 53 (2): 288-311. 
